\title{
The Influence of Generative Learning Model Assisted with Wingeom Software to Student's Mathematical Learning Outcomes
}

\section{Pengaruh Model Pembelajaran Generatif Berbantu Software Wingeom terhadap Hasil Belajar Matematika Siswa}

\author{
Yunio Hindriyanto (*) \\ Universitas Muhammadiyah Prof. DR. Hamka, Jl. Tanah Merdeka, Kp. Rambutan. \\ Meyta Dwi Kurniasih \\ Universitas Muhammadiyah Prof. DR. Hamka, Jl. Tanah Merdeka, Kp. Rambutan.
}

Received: July 4, 2018

Revised: October 18, 2018

Accepted: October 22, 2018

\begin{abstract}
The purpose of the research aims at identifying the influence of student's mathematical learning outcomes from a generative learning model assisted through Wingeom Software. The research was conducted at SMP 262 in April 2018 of the 2017/2018 academic year. The research employed a Quasi-Experiment method with cluster random sampling from two classes, that is, VIII-A and VIII-B. The research instrument used the test essay of student's Mathematical learning outcomes of which the eight items considered as to be valid and reliable. The normality test was carried out by using Liliefors while the homogeneity test uses the Fisher test. The finding shows that class VIII-A taught by generative learning model assisted through Wingeom Software has higher values than the class with no generative learning model implementation. In conclusion, the average value of students taught by a generative learning model assisted through Wingeom Software is considered to be higher than the ones who are not imposed by the generative learning model.

Keywords: Generative learning model, Wingeom software, student's mathematical learning outcomes
\end{abstract}

(*) Corresponding Author: $\quad$ yunio.h18@gmail.com

How to Cite: Hindriyanto, Y. \& Kurniasih, M. D. (2018). The influence of generative learning model assisted with wingeom software to student's mathematical learning outcomes. Formatif: Jurnal Ilmiah Pendidikan MIPA, 8 (3): 225-232. http://dx.doi.org/10.30998/formatif.v8i3.2614

\section{PENDAHULUAN}

Pendidikan merupakan hal terpenting yang harus dimiliki setiap individu siswa. Matematika memegang peranan terpenting di pendidikan. Matematika merupakan ilmu yang mengajarkan berpikir logis dan berstruktur (Kurniasih, 2017). Matematika juga sebagai mata pelajaran yang ada di semua jenjang pendidikan mulai dari sekolah dasar sampai perguruan tinggi dengan maksud membekali siswa dengan beragam kemampuan. Hal ini tertera dalam tujuan dari pembelajaran matematika ialah untuk memahami konsep matematika, menggunakan penalaran, memecahkan masalah, mengomunikasikan gagasan, memiliki sikap menghargai kegunaan matematika dalam kehidupan 
Formatif: Jurnal Ilmiah Pendidikan MIPA

Vol. 8, No. 3, Desember 2018, pp. 225-232

p-ISSN: 2088-351X

e-ISSN: $2502-5457$

DOI: http://dx.doi.org/10.30998/formatif.v8i3.2614

(Permendiknas, 2006). Tujuan dari pembelajaran matematika ini dapat dicapai dengan memaksimalkan hasil belajar matematika siswa dengan optimal.

Hasil belajar adalah puncak dari kegiatan belajar yang menghasilkan perubahan dalam pengetahuan (kognitif), sikap (afektif), dan tingkah laku (psikomotor) yang berkesinambungan dan dinamis serta dapat diukur atau diamati (Suhendri, 2011). Siswa yang mengoptimalkan hasil belajar matematika dengan baik akan terbiasa dalam menghadapi soal yang sulit maupun soal yang berkaitan masalah kehidupan sehari-hari. Namun, kenyataannya berdasarkan penelitian dari lembaga-lembaga internasional hasil belajar matematika siswa di Indonesia masih tergolong rendah. Hasil wawancara oleh guru matematika yang dilakukan di SMP Negeri 1 Argamakmur diketahui bahwa hasil belajar siswa masih tergolong rendah ini dilihat khususnya kelas VII-D dengan rata-rata 52,5 serta standar ketuntasan belajar sebesar 6,00 (Nurul, 2012). Berdasarkan hasil penelitian ini dapat disimpulkan bahwa literasi matematika siswa yang kurang menyebabkan hasil belajar matematika siswa masih tergolong rendah. Rendahnya hasil belajar matematika siswa disebabkan oleh beberapa faktor antara lain siswa menerima pelajaran dengan pasif, kurangnya siswa dalam mengulang pelajaran yang telah dipelajari sebelumnya, dan siswa masih kurang berani dalam menyampaikan pendapat saat pelajaran.

Rendahnya hasil belajar matematika siswa dapat diatasi dengan membuat perencanaan pembelajaran. Suryadi mengatakan "to achieve the competencies set in the curriculum, teachers are required to describe teaching and learning activities in the form of teaching planning" (Nurafni, Siswanto \& Azhar, 2018). Artinya guru harus dapat merencanakan kegiatan pembelajaran yang menunjukkan atmosfer pembelajaran yang menyenangkan, sehingga tujuan pembelajaran dapat tercapai (Leonard, 2018). Guru yang telah membuat perencaan pembelajaran dapat memilih model pembelajaran yang sesuai dengan materi yang sedang dipelajari sehingga siswa akan belajar lebih aktif. Model pembelajaran generatif merupakan suatu kerangka konseptual pembelajaran yang dapat membantu guru dalam membuat pembelajaran lebih aktif dan melatih siswa dalam menyapaikan pendapat yang dimiliki.Osborne dan Cosgrove mengatakan pembelajaran generatif adalah suatu model pembelajaran yang menekankan pada pengintegrasian secara aktif pengetahuan baru dengan menggunakan pengetahuan yang sudah dimiliki siswa sebelumnya (Mawadah \& Anisah, 2015). Model pembelajaran generatif terdiri dari empat tahapan yaitu tahap eksplorasi, tahap pemfokusan, tahap tantangan, dan tahap penerapankonsep (Wena, 2011). Tahapan-tahapan ini membuat siswalebih aktif dalam menyapaikan pendapat yang dimiliki saat pembelajar.

Selain pemilihan model pembelajaran yang tepat, keberhasilan dalam mempengaruhi hasil belajar matematika juga dapat didukung dengan media pembelajaran. Software Wingeom merupakan media pembelajaran matematika berbentuk aplikasi komputer yang dapat membantu guru dalam menvisualisasikan sebuah gambar bangun 2D maupun bangun 3D. Penggunaan software Wingeom ini akan membantu guru dalam menyampaikan informasi kepada siswa dengan baik. Software Wingeom dapat membantu siswa dan guru dalam mencari luas permukaan dan volume dari bangun ruang dengan mudah. Penggunaan software Wingeom saat pembelajaran akan lebih menarik dan inovatif. Kelebihan software Wingeom ini dapat membantu guru dalam pembelajaran geometri. Pembelajaran adalah proses penyusunan informasi dan penataan lingkungan dalam proses penemuan ilmu pengetahuan (Pinahayu et al, 2018). Pengertian lingkungan tidak hanya berarti tempat belajar, tetapi juga termasuk di dalamnya adalah metode, media, dan instrumen yang dibutuhkan untuk menyampaikan informasi dan membimbing siswa belajar. Informasi yang akan disampaikan dan lingkungan yang akan ditata bersifat 
fleksibel, tergantung pada tujuan pembelajaran yang ingin dicapai.Pembelajaran menggunakan software Wingeom di kelas, dirasa menjadi lebih menarik dan tidak monoton (Gusnidar, 2017). Untuk itu guru harus dapat menggunakan media komputer seperti software Wingeom sehingga proses pembelajaran menjadi lebih menyenangkan dan mendapatkan mempengaruhi hasil belajar matematika siswa lebih baik.

Berdasarkan uraian di atas, penelitaian ini bertujuan untuk mengetahui pengaruh model pembelajaran generatif berbantu software Wingeom terhadap hasil belajar matematika siswa di SMP Negeri 262 Jakarta.

\section{METODE}

Populasi dalam penelitian ini adalah seluruh siswa kelas VIII SMP Negeri 262 Jakarta tahun ajaran 2017/2018. Adapun teknik pengambilan sampel yang digunakan adalah cluster random sampling dan diperoleh dua sub populasi yaitu kelas VIII-A yang berjumlah 33 siswa menjadi kelas eksperimen dan VIII-B yang berjumlah 29 siswa menjadi kelas kontrol dalam penelitian.

Metode penelitian yang digunakan pada penelitian ini adalah metode quasi eksperimental method (Sugiyono, 2015) karena dalam penelitian ini ada dua kelompok yang dibandingkan dan diberikan perlakuan yang berbeda dengan kelas eksprimen diterapkan model pembelajaran generatif berbantu software Wingeom dan kelas kontrol tidak diterapkan model pembelajaran generatif berbantuan software Wingeom tanpa mengubah komposisi kelompok tersebut. Sedangkan desain penelitian yang digunakan dalam penelitian ini menggunakan desain sebagai berikut:

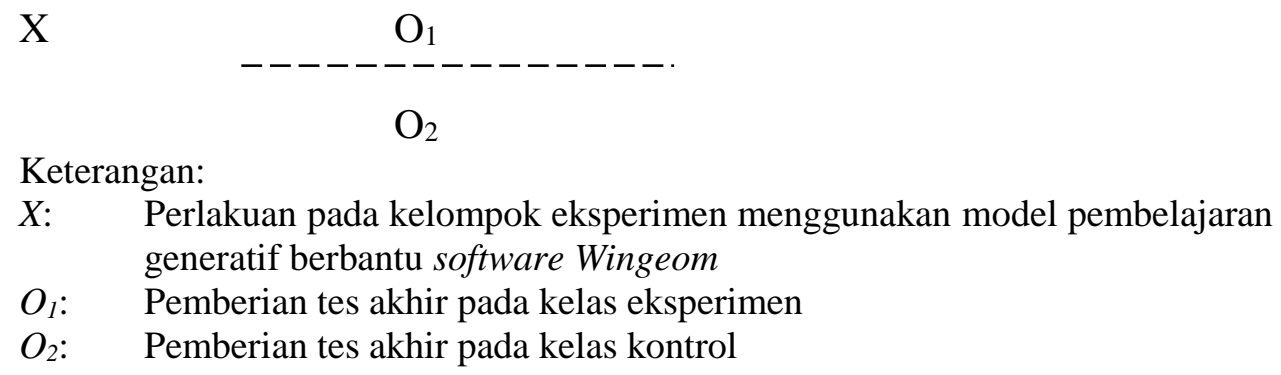

Instrumen yang digunakan dalam penelitian ini adalah tes essay untuk mengukur hasil belajar matematika siswa yang dilakukan uji validitas terdapat delapan soal yang valid. Setelah itu, dilakukan uji reabilitas didapat bahwa hasil instrument memiliki reliabel yang tinggi. Salah satu tes essay yang digunakan untuk mengukur keberhasilan siswa dalam memmahami materi bangun ruang sisi datar yaitu Ani memiliki kertas kado berukuran $60 \mathrm{~cm} \times 40 \mathrm{~cm}$ digunakan untuk membungkus sebuah kado berbentuk kubus yang memiliki ukuran sisinya $15 \mathrm{~cm}$. Bagaimana cara menentukan sisa kertas kado yang dimiliki Ani setelah membungkus kado. Tes essay digunakan peneliti untuk mengukur kemampuan dalam memenuhi indikator dari menghitung luas permukaan balok.

Analisis data penelitian menggunakan uji- $t$ untuk mengetahui apakah terdapat pengaruh hasil belajar matematika siswa dengan menggunakan model pembelajaran generatif berbantu software Wingeom. Sebelum melakukan analisis data perlu dilakukan uji persyaratan yaitu uji normalitas dengan uji Lilliefors dan uji homogenitas dengan menggunakan uji Fisher. 
Formatif: Jurnal Ilmiah Pendidikan MIPA

Vol. 8, No. 3, Desember 2018, pp. 225-232

p-ISSN: 2088-351X

e-ISSN: 2502-5457

DOI: http://dx.doi.org/10.30998/formatif.v8i3.2614

\section{HASIL DAN PEMBAHASAN}

\section{Hasil}

Penelitian ini berlangsung selama 7 pertemuan yang termasuk tes dari hasil belajar matematika siswa dengan materi bangun ruang sisi datar pada pertemuan terakhir. Pertemuan pertama peneliti menerapkan model pembelajaran dikelas dengan menggunkan model pembelajaran generatif tanpa menggunakan bantuan software Wingeom perlakuan ini dilakukan juga pada pertemuan keempat dan keenam. Pada pertemuan kedua, ketiga, dan kelima peneliti menerapkan model pembelajaran generatif berbantu software Wingeom hal ini dikarenakan penggunaan software Wingeom pada submateri pada pertemuan ini sangat membantu untuk mempermudah pembelajaran. Hasil perhitungan yang diperoleh dari data penelitian diperlihatkan dalam tabel 1 .

Tabel 1. Hasil Data Statistik Setelah Diberikan Perlakukan

\begin{tabular}{cccc}
\hline No & Keterangan & Kelas Eksperimen & Kelas Kontrol \\
\hline 1 & $\mathrm{X}$ & 38,548 & 34,172 \\
2 & $\mathrm{X}_{\max }$ & 58 & 53 \\
3 & $\mathrm{X}_{\min }$ & 18 & 17 \\
4 & Standar Deviasi & 10,308 & 8,816 \\
\hline
\end{tabular}

Berdasarkan tabel 1 terlihat bahwa rata-rata skor hasil belajar matematika siswa kelas eksperimen lebih tinggi dibandingkan rata-rata skor hasil belajar matematika siswa kelas kontrol. Untuk mengetahui pengaruh rata-rata disebabkan perlakuan atau hanya kebetulan maka dilakukan uji- $t$. sebelum dilakukan uji- $t$ maka dilakukan uji normalitas dan homogenitas.

Uji normalitas ini untuk mengetahui apakah data yang didapat dari penelitian kelas eksperimen dan kelas kontrol berdistribusi normal atau tidak. Hasil analisis uji normalitas disajikan pada tabel 2 .

Tabel 2. Hasil Uji Normalitas

\begin{tabular}{ccc}
\hline Variable & Nilai Kelas Eksperimen & Nilai Kelas Kontrol \\
\hline $\mathrm{L}_{\text {hitung }}$ & 0,1217 & 0,1217 \\
$\mathrm{~L}_{\text {tabel }}$ & 0,1591 & 0,1645 \\
\hline
\end{tabular}

Hasil uji normalitas dari dua kelas dapat disimpulkan berdistribusi normal dengan memenuhi kriteria pengujian $L_{\text {hitung }}<L_{\text {tabel }}$. Setelah ini, dilakukan uji homogenitas untuk menguji apakah data dari dua kelas homogen atau heterogen. Hasil uji homogenitas data disajikan pada tebel berikut:

Tabel 3. Hasil Uji Homegenitas

\begin{tabular}{cc}
\hline Variable & Nilai \\
\hline $\mathrm{F}_{\text {hitung }}$ & 1,367 \\
$\mathrm{~F}_{\text {tabel }}$ & 1,87 \\
\hline
\end{tabular}

Berdasarkan tabel 3 diketahui $F_{\text {hitung }}<F_{\text {tabel }}$, maka dapat disimpulkan kedua data kelas tersebut homogen. Karena kedua data normal dan homogen dapat dilakukan 
analisis dengan menggunakan uji-t. Hasil analisis uji hipotesis dari skor hasil belajar matematika siswa ditunjukkan dalam tabel 4.

Tabel 4. Hasil Uji Hipotesis

\begin{tabular}{cc}
\hline Variable & Nilai \\
\hline $\mathrm{t}_{\text {hitung }}$ & 1,762 \\
$\mathrm{t}_{\text {tabel }}$ & 1,671 \\
\hline
\end{tabular}

Hasil uji hipotesis menggunakan $\alpha=5 \%$ (Sudjana, 2005). Berdasarkan tabel diatas diketahui $t_{\text {hitung }}>t_{\text {tabel }}$ maka tolak $\mathrm{H}_{0}$ dan terima $\mathrm{H}_{1}$ dan dapat disimpulkan bahwa ada pengaruh model pembelajaran generatif berbantu software Wingeom terhadapt hasil belajar matematika siswa.

\section{Pembahasan}

Secara umum kualitas proses pembelajaran dan hasil belajar matematika dapat ditingkatkan melalui penggunaan model pembelajaran generatif dan dibantu media pembelajaran. Penggunaan model pembelajaran generatif dapat membantu guru untuk membuat pembelajaran di kelas lebih aktif. Model pembelajaran generatif terjadi layaknya sebuah generator yang sedang bekerja, dimana semua elemen dalam generator dapat memberikan terbangun aktif memainkan perannya masing-masing (Hakim, 2014). Tahapan model pembelajaran generatif yang terdiri dari 4 tahap yaitu tahap eksplorasi, tahap pemfokusan, tahap tantangan dan penerapan konsep.

Tahap pertama yaitu tahap eksplorasi guru membimbing siswa dalam melakukan eksplorasi terhadap pengetahuan, ide dan konsep pada pembelajaran sebelumnya, pada tahap kedua yaitu tahap pemfokusan merupakan pengenalan konsep dimana siswa melakukan kegiatan laboratorium dan pada tahap ini guru menjadi fasilitator. Tahap ketiga yaitu tahap tantang merupakan langkah dimana siswa dilatih dalam menyapaikan pendapat, ide atau gagasan yang dimiliki. Lalu tahap terakhir yaitu tahap penerapan konsep siswa pada tahap ini menggunakan konsep baru yang meraka miliki untuk diaplikasikan dalam mengatasi pada permasalahan yang ada (Lestari \& Yudhanegara, 2017). Tahap-tahap ini membantu siswa lebih aktif saat pembelajaran, siswa juga berani dalam menyampaikan pendapat yang dimilki dan siswa belajar dalam menghargai pendapat orang lain. Penelitian yang dilakukan oleh (Mawadah \& Anisah, 2015) juga menyatakan bahwa siswa lebih aktif dalam pembelajaran, melatih siswa dalam mengemukakan pendapat, memotivasi siswa untuk bekerja sama dengan baik dalam kelompok. Berdasarkan penelitian diatas model pembelajaran dapat membantu guru dalam mempengaruhi hasil belajar matematika siswa dengan menciptakan pembelajaran yang menarik dan aktif.

Selain, pemilihan model pembelajaran yang tepat hasil belajar matematika juga dapat didukung dengan media pembelajaran.penggunaan media pembelajaran yang refresentatif telah meningkatkan minat belajar siswa yang berdampak pada hasil belajar matematika siswa (Tatan \& Sumiati, 2011). Penggunaan media tersebut sangatlah penting, sebagaimana telah dijelaskan dalam kurikulum 2013, yakni salah satu prinsip pembelajaran dalam kurikulum 2013 menekankan pada perubahan paradigma pemanfaatan teknologi informasi dan komunikasi untuk meningkatkan efisiensi dan efektivitas pembelajaran. Software Wingeom merupakan media pembelajaran dalam bentuk aplikasi komputer yang dapat memvisualisakan gambar 2D dan 3D sehingga pembelajaran lebih menarik. Software Wingeom ini dapat digunakan untuk membuat 
bangun ruang secara 3D sehingga siswa lebih memahami materi yang dipelajari. Selain itu, software Wingeom ini dapat menghitung luas permukaan dan volume dari bangun ruang secara praktis. Pembelajaran menggunakan software Wingeom di kelas menjadi lebih menarik dan tidak monoton

Penelitian yang dilakukan oleh Gusnindar et al (2017) juga menyatakan bahwa berdasarkan hasil penelitian menunjukan bahwa pembelajaran yang menggunakan penerapan strategi pembelajaran ekspositori berbantu software Wingeom akan membantu siswa dalam memvisulalisasikan konstruksi balok dalam tiga dimensi, sehingga membuat siswa lebih mudah dalam mengingat materi pembelajaran tersebut. Jadi, berdasarkan hasil penelitian yang dilakukan, ternyata model pembelajaran generatif berbantu software Wingeom mempunyai pengaruh terhadap hasil belajar matematika siswa.

\section{PENUTUP}

Berdasarkan hasil penelitian yang dilakukan, ternyata model pembelajaran generatif berbantu software Wingeom mempunyai pengaruh terhadap hasil belajar matematika siswa. Hal ini dapat dilihat dari rata-rata hasil belajar matematika siswa di kelas yang menggunakan model pembelajaran generatif berbantu software Wingeom lebih tinggi dibandingkan dengan rata-rata hasil belajar siswa dikelas yang tidak menggunakan model pembelajaran generatif berbantu software Wingeom. Hal ini menunjukkan bahwa model pembelajaran generatif berbantu software Wingeom mempunyai pengaruh terhadap hasil belajar matematika siswa. Sesuai kriteria pengujian, $\mathrm{H}_{0}$ diterima jika $t_{\text {hitung }}<$ $t_{\text {tabel }}$, dan $\mathrm{H}_{0}$ ditolak jika $t_{\text {hitung }}>t_{\text {tabel }}$ karena $t_{\text {hitung }}>t_{\text {tabel }}$ maka $\mathrm{H}_{0}$ ditolak. Jadi, dapat disimpulkan bahwa ada pengaruh model pembelajaran generatif berbantu software Wingeom terhadap hasil belajar matematika di SMP Negeri 262 Jakarta.

Setelah pelaksanaan penelitian dan pembahasan hasil penelitian, penulis mengharapkan beberapa hal sebagai berikut:

1. Diharapkan guru-guru matematika untuk sering berinovatif dalam menggunakan model pembelajaran, sehingga lebih menuntut siswa terlatih dalam menghadapi soal matematika yang berkaitan dengan kehidupan sehari-hari.

2. Pembelajaran menggunakan model pembelajaran generatif berbantu software Wingeom pada materi bangun ruang sisi datar belum mencapai hasil yang optimal, sehingga penulis menyarankan kepada pihak-pihak yang akan menggunakan model pembelajaran generatif berbantu software Wingeom didalam pembelajaran matematika untuk lebih memperhatikan setiap tahapan yang dilakukan agar lebih menciptakan proses belajar yang lebih baik.

3. Diharapkan para guru untuk lebih memberikan kesadaran akan pentingnya belajar matematika kepada siswa, sehingga siswa dapat menyelesaikan masalah yang dihadapi dalam kehidupan dan medapat hasil belajar matematika yang optimal dalam pembelajaran.

\section{DAFTAR PUSTAKA}

Gusnindar, et al. (2017). Implementasi strategi pembelajaran konflik kognitif berbantuan software Wingeom dalam meningkatkan kemampuan pemecahan masalah matematis. JEMS (Jurnal Edukasi Matematika dan Sains), 5 (2), 62-69. Retrieved from: http://e-journal.unipma.ac.id/index.php/JEMS/article/view/1988 
Hakim, A. R. (2014). Pengaruh model pembelajaran generatif terhadap kemampuan pemecahan masalah matematika. Formatif: Jurnal Ilmiah Pendidikan MIPA, 4 (3), 196-207. Retrieved from: http://journal.lppmunindra.ac.id/index.php/Formatif/article/view/155

Kurniasih, M. D. (2017). Pengaruh pembelajaran react terhadap kemampuan berpikir kritis matematis ditinjau dari habit of mind mahasiswa. Kalamatika Jurnal pendidikan matematika, 2 (1): 29-38. http://kalamatika.matematikauhamka.com/index.php/kmk/article/view/48

Leonard, L. (2018). Task and forced instructional strategy: Instructional strategy based on character and culture of Indonesia nation. Formatif: Jurnal Ilmiah Pendidikan MIPA, 8(1), 51-56. http://doi.org/10.30998/formatif.v8i1.2408

Lestari, K. E. \& Mokhamad. R.Y. (2017). Penelitian Pendidikan Matematika. Bandung: PT Refika Adimat.

Mawadah, S. \& Anisah, H. (2015). Kemampuan pemecahan masalah matematis siswa pada pembelajaran matematika menggunakan model pembelajaran generatif (generative learning) di SMP. EDU-MAT Jurnal Pendidikan Matematika, 3 (2): 166-175.

http://download.portalgaruda.org/article.php?article $=444169 \& v a l=9364 \&$ title

Nurafni, Siswanto, R D., \& Azhar, E. (2018). Development of geometry material based on scientific approach for junior high school student. IOP Conf. Series: Journal of Physics: Conf. Series 948: 1-4. http://iopscience.iop.org/article/10.1088/17426596/948/1/012002

Permendiknas. (2006). Standar isi untuk satuan pendidikan dasar dan menengah. Jakarta: Pemendikanas.

Pinahayu, E. A. R., et al. (2018). Implementasi aplikasi Wingeom untuk pengembangan bahan ajar di SMP. Jurnal PKM: Pengabdian kepada Masyarakat, 1(2): 112-121.

Sudjana. (2005). Metode Statistika. Bandung: Tarsito Bandung.

Sugiyono. (2015). Metode Penelitian Pendidikan Pendekatan Kuantitatif, Kualitatif dan $R \& D$. Bandung: ALFABETA.

Suhendri, H. (2011). Pengaruh kecedasan matematis-logis dan kemandirian belajar terhadap hasil belajar matematika. Formatif: Jurnal Ilmiah Pendidikan MIPA, 1 (1), 29-39. http://journal.lppmunindra.ac.id/index.php/Formatif/issue/view/16

Tatan Z. M \& Sumiati, T. (2011). Pengaruh penggunaan media belajar dan minat belajar terhadap hasil belajar matematika (eksperimen pada siswa kelas XI IPA SMA Negeri 8 Kota Tangerang Selatan Tahun Pelajaran 2010/2011). Formatif: Jurnal Ilmiah Pendidikan MIPA, 1 (1). http://journal.lppmunindra.ac.id/index.php/Formatif/article/view/64/57

Wena, M. (2011). Strategi Pembelajaran Inovatif Kontenporer. Jakarta: Bumi Aksara.

Nurul Astuty Yensy B. (2012). Penerapan model pembelajaran kooperatif tipe examples non examples dengan menggunakan alat peraga untuk meningkatkan hasil belajar siswa di kelas VIII SMP N Argamakmur. Jurnal Exacta, 10 (1), 24-35. http://repository.unib.ac.id/490/ 
Formatif: Jurnal Ilmiah Pendidikan MIPA

Vol. 8, No. 3, Desember 2018, pp. 225-232

p-ISSN: 2088-351X

e-ISSN: 2502-5457

DOI: http://dx.doi.org/10.30998/formatif.v8i3.2614 